\title{
Creativity, innovation and entrepreneurship: a new prescription for health care
}

\author{
This article was published in the following Dove Press journal: \\ Innovation and Entrepreneurship in Health \\ 15 April 2014 \\ Number of times this article has been viewed
}

\section{Rubin Pillay \\ Center for Health Systems Innovation, Spears School of Business and Center for Health Sciences, Oklahoma State University, Stillwater, OK, USA}

Innovation and Entrepreneurship in Health is in its first year. The turnaround time for the publishing of manuscripts is a few weeks. Peer reviews are high quality, and the journal is open access, filling an important niche in "pracademic" publishing. Special focus will be given to the theory, process, and practice of innovation and entrepreneurship by individuals and organizations within the health care context globally. This journal is directed at academics conducting research and teaching in this area, as well as practitioners who are looking for creative and innovative solutions to the vexing problems of cost, quality, and access encountered by most health care organizations and systems. It gives academics and practitioners a forum for circulating ideas and research aimed at improving managerial practice and public policy. The journal publishes original research papers, cases of innovations that have been implemented and scaled, essays containing deeper analysis than is available in blogs or opinion-editorial pages, and comments from readers.

We are living through what is arguably the most challenging time for the health care industry. Globally, health care appears to be on a collision course with patient needs and economic reality. No one is happy with the current system, and the combination of rising costs, poor access, inequitable care, and diminishing quality and safety has created anxiety and frustration for all. Decades of interventions have failed to improve the situation; if anything, things have become worse. Current approaches tend to focus on a single issue or problem (the price of drugs, rising numbers without medical aids, provider incentives to over treat), but an overarching solution has remained elusive.

Clearly, the time has come for a radical reconsideration of our approach, one based on the trajectory of well-functioning industries. The health care status quo is poised to be revolutionized by two forces: technology and consumerism. The purpose of this editorial is to help you get a realistic grasp on and understand and recognize the opportunities and disruptive influences of exponentially growing technologies and converging fields within health and health care; specifically, how rapidly developing technologies such as low-cost genomic sequencing, artificial intelligence, threedimensional printing, telemedicine, robotics, 24/7 body wearable monitors, smart pills, stem cells, synthetic biology, gene therapy, mobile phone applications, and crowd-sourced health data are bound to affect the future of health and health care. So whether you are a policymaker, payer, provider, or patient, you need to prepare for a world of health care abundance, but only if we change our prescription.
Center for Health Systems Innovation, Spears School of Business and Center for Health Sciences, Oklahoma State University, Stillwater, OK, USA

Email rubin.pillay@okstate.edu submit your manuscript | www.dovepress.com

Dovepress

http://dx.doi.org/10.2147/IEH.S59263
Innovation and Entrepreneurship in Health 20I4: I I-3

(c) (i) (c) 2014 Pillay. This work is published by Dove Medical Press Limited, and licensed under Creative Commons Attribution - Non Commercial (unported, v3.0) License. The full terms of the License are available at http://creativecommons.org/licenses/lyy-nc/3.0/. Non-commercial uses of the work are permitted without any further permission fovi Dove Medical Press Limited, provided the work is properly attributed. Permissions beyond the scope of the License are administered by Dove Medical Press Limited. Information on how to request permission may be found at: http://www.dovepress.com/permissions.php 
The fundamental problem with health systems in general is that health outcomes are not commensurate with what we spend, with our human resource capacity and capability, and with current technology advancements. In short, we get out much less than we put in. This performance potential gap is inconceivable in a well-functioning market. The solution for health is therefore in creating value or, put very simply, in getting more out than we put in. As simple and obvious as this seems to be, creating value has not been the central goal of health care, especially for those tasked with managing it. Current approaches to health management tend to focus on maintaining the status quo or, usually, making unnoticeable incremental efficiency improvements (if we are lucky), which in effect amounts to a loss of value, given what this costs us and what is available to us.

So how does one create value in health care? Simple: By using the same value-creating processes and activities that Albert Einstein, Walt Disney, Steve Jobs, Richard Branson, Larry Page, and a host of others used to ensure that their organizations and industries performed close to their maximal potential. They were creative, innovative, and entrepreneurial, and they encouraged, enhanced, and enabled their teams and organizations to be the same. These are not the particular endowment of a lucky few people or organizations but the result of skills and abilities that can be learned by anyone. These skills and abilities are sorely needed in health care if we are to come close to fulfilling the potential of the system as a whole and to achieving an era of health care abundance.

Creativity is our ability to generate new and useful ideas that can be put to work in our personal or business lives. It is a specific and practical technique (it is not intelligence) that can be learned and is critical in allowing us to rethink the way we see things as well as help us generate the ideas and creative solutions we need to solve the challenges we face daily as health policymakers, managers, care providers, or patients. Amazingly, none of us is taught this, and we are never assessed for this when we are being evaluated for education or job opportunities. I think this is a critical caveat in our education and training system (not unique to health care), but as important as this competence is, the real value creation still exists in the mind of the individual and needs to be translated into something tangible, useful, and useable. In this case, it needs to be translated to improving health and health care delivery.

This ability to translate a novel idea into a product, service, process, or business model that is actionable and has value to the user is known as innovation. This includes making existing products, services, and processes available to those who previously had no access to them. The latter is particularly relevant for health care in developing country contexts, as the key to improving access and equity and reducing costs will depend on leveraging existing exponential and converging technologies (such as cell phone technology and genomics) that are set to fuel the medical revolution. However, incremental process innovations based on those of industry leaders in other sectors (eg, on Toyota's production systems or Wal-Mart's supply chain management) are also extremely important to achieve efficiencies and should occur in parallel. These could be clinical process innovations or innovations in all the secondary or supporting activities associated with the delivery of care. Once again, the ability to innovate can be learned, but it is stark in its absence from programs aimed at training health sector professionals and managers. However, although all of these innovations and the ability to innovate are inherently valuable, they are meaningless if they are not made available to the masses.

Entrepreneurship is the process of taking innovations to the market or applying them widely within organizations, irrespective of the constraints one faces. Entrepreneurs are not born, they are individuals who have mastered the practice (by learning) of being innovative, proactive, and adept at managing risk and who possess the ability to get things done despite the contexts within which they find themselves. We desperately need this caliber of individual to effect change within health organizations and within the system as a whole. Instead, we are saddled with administrators and managers, a far cry from what we need to transform the system.

We have reached the tipping point in health care and now, more than ever, we need all players, especially leaders, to adopt and propound creativity, innovation, and entrepreneurial thinking and behavior as a major catalyst to effect positive change in our health and in health care delivery. We need people who can create value at all levels: mind, matter, and market. Clearly, for health care to change, we can start by training those responsible for delivering health care and those overseeing the delivery of care to be creative, innovative, and entrepreneurial.

\section{Disclosure}

The author has no conflicts of interest to disclose. 


\section{Publish your work in this journal}

Innovation and Entrepreneurship in Health is an international, peer reviewed, open access journal publishing original research, reports, reviews and commentaries on innovation and entrepreneurship in health. Special focus will be given to the theory, process, and practice of innovation and entrepreneurship by individuals and organizations within the health care context globally. The manuscript management system is completely online and includes a very quick and fair peer review system, which is all easy to use. Visit http://www.dovepress.com/ testimonials.php to read real quotes from published authors.

Submit your manuscript here: http://www.dovepress.com/innovation-and-entrepreneurship-in-health-journal 